\title{
TRENDS IN OZONE CONCENTRATIONS IN THE IBERIAN PENINSULA BY QUANTILE REGRESSION AND CLUSTERING
}

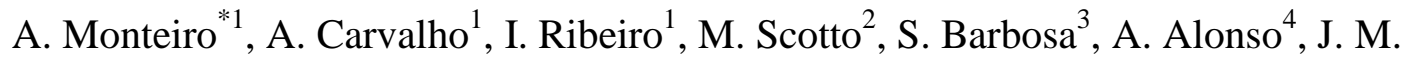 \\ Baldasano $^{5,6}$, M. T. Pay ${ }^{5}$, A.I. Miranda ${ }^{1}$, C. Borrego ${ }^{1}$ \\ ${ }^{1}$ CESAM \& Department of Environment and Planning, University of Aveiro, Aveiro, Portugal \\ ${ }^{2}$ Department of Mathematics, University of Aveiro, Aveiro, Portugal \\ ${ }^{3}$ Center of Geophysics, IDL, University of Lisbon, Lisbon, Portugal \\ ${ }^{4}$ Departamento de Estadística, Universidad Carlos III de Madrid, Spain \\ ${ }^{5}$ Earth Science Department, Barcelona Supercomputing Center, Jordi Girona 29, Edificio Nexus II, Barcelona, Spain \\ ${ }^{6}$ Environmental Modeling Lab, Technical University of Catalonia, Barcelona, Spain \\ *Corresponding author: A. Monteiro, e-mail: alexandra.monteiro@ua.pt; Tel: +351 234 370220, Fax: +351 234 \\ 370309
}

\section{Abstract}

In this paper, 10-years of ozone $\left(\mathrm{O}_{3}\right)$ hourly concentrations collected over the period 2000-2009 in the Iberian Peninsula (IP) are analyzed using records from 11 background sites. All the selected monitoring stations present an acquisition efficiency above $85 \%$. The changes in tropospheric ozone over the Iberian Peninsula are examined by means of quantile regression, which allows to analyse the trends not only in the mean but in the overall data distribution. In addition, the ozone hourly concentrations records are clustered on the basis of their resulting distributions.

The analysis showed that high altitude stations $(>900 \mathrm{~m})$ have higher background $\mathrm{O}_{3}$ concentrations $(\sim 80$ $\left.\mu \mathrm{g} . \mathrm{m}^{-3}\right)$. The same magnitude of background $\mathrm{O}_{3}$ concentrations is found in stations near the Mediterranean Sea. On the other hand, the rural stations near the Atlantic coast present lower background values $\left(\sim 50-60 \mu \mathrm{g} \cdot \mathrm{m}^{-3}\right)$ than those of Mediterranean influence. The two sub-urban stations exhibit the lowest background concentrations $\left(\sim 4 \mu \mathrm{g} \cdot \mathrm{m}^{-3}\right)$. The results of the quantile regression show a very distinct behaviour of the data distribution, the slopes for a fixed quantile are not the same over IP, reflecting the spatial dependence of $\mathrm{O}_{3}$ trends. Hence the rate of temporal change is not the same for all parts of the data distribution, as implicitly assumed in ordinary regression. The lower quantile (percentile 5) presents higher rates of change than the middle (percentile 50) and the upper quantile (percentile 95). The clustering procedure reveals what has been already detected in the quantile regression. The station with highest rates of decrease on the $\mathrm{O}_{3}$ concentrations (easternmost station of IP) is isolated and then other clusters are formed among the moderately positive/negative $\mathrm{O}_{3}$ trends around the IP. The clustering procedure highlighted that the largest trends are found for the lower ozone $\mathrm{O}_{3}$ values, with largest negative trend at the easternmost station of IP, and also in northern and mainland stations, and an opposite behaviour, with positive $\mathrm{O}_{3}$ trends, is observed at the Atlantic coast stations. 
41 Keywords: Iberian Peninsula; tropospheric ozone; spatial and temporal analysis; quantile regression; cluster procedure

\section{INTRODUCTION}

Tropospheric ozone $\left(\mathrm{O}_{3}\right)$ is a key determinant of the atmospheric oxidation state and a major constituent of photochemical smog which impacts air quality at urban and regional scale. The production of elevated levels of $\mathrm{O}_{3}$ at ground level is of particular concern because it is known to have adverse effects on human health, vegetation, and a variety of materials (EA, 2010a). There is a high interest in quantifying surface $\mathrm{O}_{3}$ concentrations and associated trends, as they serve to indirectly quantify the impacts of the anthropogenic precursor reductions and to evaluate the effects of emission control strategies (Tang et al., 2006; Sicard et al., 2009).

There have been a few studies on the analysis of surface $\mathrm{O}_{3}$ trends in different regions of Europe (Brönnimann et al., 2002, Jenkin, 2008; Sicard et al., 2009). Over the Iberian Peninsula (IP) where high surface $\mathrm{O}_{3}$ concentrations are monitored each year from April to September (EEA, 2010b), several analyses of surface $\mathrm{O}_{3}$ concentrations have been carried out. However, they were limited to a single location restricted to a region of the IP and adopting an ordinary regression approach or based on the median/mean and high percentile $\mathrm{O}_{3}$ analysis (Gimeno et al., 1999; Millán et al., 2002; Ribas and Peñuelas, 2004; Adame et al., 2008).

Observations from background monitoring stations have revealed that baseline surface $\mathrm{O}_{3}$ concentrations in the northern hemisphere have been increasing over the past three decades (Marenco et al., 1994), with average increases of approximately $0.5-2 \%$ per year at northern mid-latitudes (Vingarzan, 2004). The observed increasing trend in baseline $\mathrm{O}_{3}$ concentrations is believed to be driven by emissions and processing of $\mathrm{O}_{3}$ precursors on a global scale (Jaffe et al., 2003; Honrath et al., 2004; Derwent et al., 2006, 2007). Although this hemispheric baseline influences $\mathrm{O}_{3}$ concentrations throughout the IP, the observed concentrations can be further modified by processes occurring on regional- and local-scales, which can both increase and decrease $\mathrm{O}_{3}$ levels. Therefore such processes occurring on local, regional, and global scales have an influence on whether $\mathrm{O}_{3}$ air quality standards at a given location are achieved (Jenkin, 2008). Although the progressive control of $\mathrm{O}_{3}$ precursors emissions -like volatile organic compounds (VOC) and nitrogen oxides $\left(\mathrm{NO}_{\mathrm{x}}\right)$ - within the European Community since the early 1990s (CEC, 1991) have influenced the magnitude of the $\mathrm{O}_{3}$ regional- and local- scale effects (Derwent et al., 2003; Jonson et al., 2005; Vautard et al., 2006), the observed $\mathrm{O}_{3}$ trends is determined from the net trend of the global-, regional- and local-scale effects, the relative contributions of which can vary both spatially and temporally. between 1990 and 2008 in Europe (EEA, 2010a). Reported European emissions of $\mathrm{NO}_{\mathrm{x}}$ and 
and Portugal, the $\mathrm{O}_{3}$ precursor emissions have also been reduced, namely for $\mathrm{NO}_{\mathrm{x}}(8 \%$ and $7 \%$, respectively) and NMVOC (21\% and 34\%, respectively).

The understanding of the $\mathrm{O}_{3}$ budget and trends in the troposphere over the IP is required to (a) properly identify the various mechanisms that contribute to the observed hourly average concentration distribution; and to (b) develop and test models capable of simulating and predicting atmospheric chemical and physical processes (Lefohn et al., 2008). It is also important to characterize the changes in the distribution of hourly average $\mathrm{O}_{3}$ concentrations which provide (a) quantitative feedback on the effects of emission reductions on $\mathrm{O}_{3}$ concentrations; (b) insights concerning the long-range transport of $\mathrm{O}_{3}$ outside IP and possible impacts of climate change; and (c) important information on which processes dominate during a specific time of the year and which processes are more likely to influence particular portions of the distribution (Oltmans et al., 2006).

Robust statistical procedures can be applied to investigate the spatial and temporal evolution of the $\mathrm{O}_{3}$ concentrations over a region from historical datasets. This study adopts the method introduced by Barbosa et al. (2011) which combines quantile regression and clustering procedures in order to better assess the spatial and the temporal evolution of the hourly $\mathrm{O}_{3}$ measurements over the IP. On the one hand, quantile regression (Koenker and Hallock, 2001) provides the rate of change not only in the mean, as in ordinary regression, but also in all parts of the data distribution. In this sense, the quantile regression quantifies the variability structure of the hourly $\mathrm{O}_{3}$ concentrations and assesses the changes in the data distribution. On the other hand, cluster analysis is an adequate procedure to spatially characterize the regional variability on the $\mathrm{O}_{3}$ data and it has been widely used in different analysis of environmental processes (Alonso et al., 2006; Scotto et al., 2009; Barbosa et al., 2011; Carvalho et al., 2011).

This work focuses on investigating the temporal and spatial trends of the hourly surface $\mathrm{O}_{3}$ concentrations at background environment over the IP for the last decade (2000-2009). The remainder of this paper is laid out as follows. Section 2 discusses the $\mathrm{O}_{3}$ concentrations acquired at the background monitoring stations used in this study. Section 3 describes the application of the quantile regression approach and the clustering procedure. Results are presented in Section 4. Finally, in Section 5 the results are discussed and main conclusions are summarized.

\title{
2. $\mathrm{O}_{3}$ DATA OVER THE IBERIAN PENINSULA
}

A total of $11 \mathrm{O}_{3}$ monitoring stations within the IP are selected taking into account their background influence and the efficiency data collection (> 85\%) during the 10-years period (2000-2009) as shown in Fig. 1 and Table 1. The spatial coverage is suitable over the IP, with two stations located in Portugal and the remaining 9 stations located over Spain.

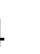

\author{
(Figure 1)
}


118 Ambient $\mathrm{O}_{3}$ concentrations are reported on an hourly basis and were obtained from the

119 Portuguese Air Quality Database (www.qualar.org) and the EMEP monitoring network 120 (www.emep.int).

121 Fig. 2 shows the distribution of hourly $\mathrm{O}_{3}$ concentrations by year. Different groups of stations can be distinguished in terms of background values (median) and minimum/peak values.

126 High altitude stations ( $>900 \mathrm{~m})(\mathrm{CPB}$, VIZ and PEN) show high background concentration $127\left(\sim 80 \mu \mathrm{g} \cdot \mathrm{m}^{-3}\right)$ due to higher $\mathrm{O}_{3}$ levels in elevated terrains. The same range of background $\mathrm{O}_{3}$ 128 concentrations are found in stations near the Mediterranean Sea (CCR, ZAR, and TOR). $\mathrm{O}_{3}$ atmospheric dynamics in the Spanish Mediterranean areas is affected by mesoscale and local meteorological processes but also regional factors, such as (Baldasano et al., 1994, Millán et al., 1997; Toll and Baldasano, 2000; Martin-Vide and Olcina, 2001; Soriano et al., 2001; Pérez et al., 2004): (1) the influence of the Azores high-pressure system, (2) the costal ranges surrounding the Mediterranean coast, (3) the influence of the Iberian and Saharan thermal lows

134 causing weak pressure gradients over the Mediterranean (4) the intense breeze action along the

135 Mediterranean coast favoured by the prevailing low advective conditions, (5) the scarce summer 136 precipitation, and (6) the intense seasonal contrast concerning temperature, humidity and 137 rainfall. All these facts favour the photochemical formation of $\mathrm{O}_{3}$ and contribute to the 138 accumulation and recirculation of aged air masses which contain $\mathrm{O}_{3}$. The two rural stations 139 closest to Portugal and located under $506 \mathrm{~m}$ of altitude -BAR and SEV - register lower median $140\left(\sim 50-60 \mu \mathrm{g} \cdot \mathrm{m}^{-3}\right)$ than those of Mediterranean influence, also presenting $\mathrm{O}_{3}$ peaks (P95) less than $141120 \mu \mathrm{g} \cdot \mathrm{m}^{-3}$. The NIB station, in the northern IP, also presents low median concentrations along 142 the decade $\left(\sim 50-60 \mu \mathrm{g} . \mathrm{m}^{-3}\right)$ due to the influence of large plumes coming from power plants 143 located in northeaster Spain (Pay et al., 2011) containing high $\mathrm{NO}_{\mathrm{x}}$ concentration that affects $\mathrm{O}_{3}$ 144 chemistry in this region. Such episodes happen under the influence of westerly winds which are 145 relatively frequent (Jorba et al., 2004). The two suburban stations (CUS and PP) exhibit the 146 lowest median $\left(\sim 45 \mu \mathrm{g} \cdot \mathrm{m}^{-3}\right)$ and the minimum $\mathrm{O}_{3}$ concentrations (P5) $\left(\sim 0 \mu \mathrm{g} \cdot \mathrm{m}^{-3}\right)$, explained by 147 the $\mathrm{O}_{3}$ destruction by $\mathrm{NO}$ (emitted by road-traffic and shipping in the urban and suburban areas 148 of Oporto and Lisbon) mainly at nigh-time (Seinfeld and Pandis, 1998).

149 During the study period the most critical years in terms of $\mathrm{O}_{3}$ peaks/episodes were 2005 and 1502006 for the majority of the stations. The summer period of these two years was characterized 151 by meteorological conditions very favourable for photochemical activity (Monteiro et al., 2005, 
152 2007). The year 2003 was also a particular critical year in terms of photochemical activity (and

153 high $\mathrm{O}_{3}$ values) due to the occurrence of a strong heat wave over the IP (Ordonez et al., 2010).

\section{STATISTICAL METHODS}

156 Quantile regression is a well-defined statistical technique for regression on quantiles rather than regression on the mean. Although it was first introduced in econometrics by Koenker and Basset (1978), quantile regression is being applied in various geoscience contexts (e.g. Koenker and Schorfheide, 1994; Cade and Noon, 2003; Baur et al., 2004; Elsner et al., 2008; Barbosa et al.,

160 2011). We outline here the essential of the quantile regression approach. The starting point is a

161 random variable $Y$ with cumulative continuous distribution function $\mathrm{F}_{\mathrm{Y}}(\mathrm{y})$ (by definition: $\mathrm{FY}(\mathrm{y})$

$162=\mathrm{P}(\mathrm{Y} \leq \mathrm{y}))$. The quantile $\tau$ is defined as the value $\mathrm{Q}_{\mathrm{Y}}(\tau)$ such that $\mathrm{P}(\mathrm{Y} \leq \mathrm{Qy}(\tau))=\tau$, for $0 \leq \tau \leq 1$.

163 The quantile function $\mathrm{Q}_{\mathrm{Y}}(\tau)$ is defined from the cumulative distribution function $\mathrm{F}_{\mathrm{Y}}(\mathrm{y})$ as $\mathrm{Q}_{\mathrm{Y}}(\tau)$

$164=\mathrm{F}_{\mathrm{Y}}^{-1}(\mathrm{y})$. Then considering the conditional distribution of $\mathrm{Y}$ given $\mathrm{X}=\mathrm{x}$, the conditional quantile 165 function $\mathrm{Q}(\mathrm{Y} \mid \mathrm{X})(\tau \mid \mathrm{x})$ verifies $\mathrm{P}(\mathrm{Y} \leq \mathrm{Q}(\mathrm{Y} \mid \mathrm{X})(\tau \mid \mathrm{x}) \mid \mathrm{X}=\mathrm{x})=\tau$. Whereas ordinary regression is based 166 on the conditional mean function $\mathrm{E}(\mathrm{Y} \mid \mathrm{X})=\mathrm{x}$ and minimization of the respective residuals, 167 quantile regression is based on the conditional quantile function and minimization of the sum of 168 asymmetrically weighted absolute residuals $\sum_{i \geq 1} \rho(\tau)\left(y_{i}-Q_{(Y \mid X)}\left(\tau \mid x=x_{i}\right)\right)$, where $\rho($.$) represents$ 169 the tilted absolute value function. For further details see Koenker (2005).

170 The time series clustering procedure proposed to classify the time series of $\mathrm{O}_{3}$ hourly 171 concentrations based on the corresponding distributions for quantile slopes at lower, middle and 172 upper quantiles is as follows: firstly, for a fixed (but arbitrary) quantile, the algorithm starts with 173 the estimation of the distribution corresponding to quantile slope estimates; second, the 174 corresponding dissimilarity matrix is computed. To this extend, an adequate metric between 175 univariate distribution functions is required. In the present setting the weighted L2-Wasserstein 176 distance between two quantile slope distributions is adopted. Finally, a dendrogram based on the 177 application of classical cluster techniques to the dissimilarity matrix is built and that provides 178 the different clusters formed by the distributions of the quantile slopes. In particular, 179 agglomerative hierarchical methods with nearest distance (single linkage), furthest distance 180 (complete linkage) and unweighted average distance (average linkage) are used as grouping 181 criteria. In order to summarise those distributions, the average linkage procedure is applied to 182 obtain dendrograms of slopes for quantiles $0.05,0.5$ and 0.95 . Similar conclusions are obtained 183 using the single linkage and the complete linkage methods.

186 In this section, quantile regression is applied for the hourly $\mathrm{O}_{3}$ concentrations in order to 187 describe the temporal variability of different quantiles of the $\mathrm{O}_{3}$ distribution over IP. The 
quantile slopes and corresponding standard errors are derived using the algorithm of Koenker

189 and D'Orey (1987). The clustering procedure is also discussed.

190 The results for all the stations are shown in Fig. 3, along with the quantile slopes at quantiles

$1910.05,0.5$ and 0.95 , corresponding respectively to the lowest $5 \%, 50 \%$ (median) and $95 \%$ of the 192 ordered observations.

(Figure 3)

Several $\mathrm{O}_{3}$ trends over the last decade can be identified in this group of stations. A significant negative trend is only exhibited by CCR station, especially for lowest quantiles (P5). The same tendency was found by Ribas and Peñuelas (2004) for a coastal station (Begur) in northeastern Spain. CCR is a costal station located in the northeastern extreme of the IP. This site presents strong north-westerly winds (tramontane and mistral) channelled by Pyrenees and Central Massif throughout the Gulf of Lyon. The flow crosses the Carcasone gap into the Mediterranean which can transport new pollutants into the area that are added to local emissions and recirculated within the coastal breezes at eastern Iberian (Gangoiti et al., 2001). CPB, PEN located in the northern Spanish plateau - and SEV show a slightly negative slope, mainly for the lower quantiles. BAR and ZAR monitoring sites don't show any significant trend for the three quantiles.

207 By contrast, the NIB coastal station in the northern IP presents the largest positive trends, even

208 larger for lower concentration (P5). Similar trends are found in TOR and VIZ, sited under the

209 Mediterranean influence, and in a lesser extend at the two suburban stations at Oporto and

210 Lisbon cities (CUS and PP, respectively).

211 A more complete description of the quantile regression results is displayed in Fig. 4 which

212 displays the quantile slopes and the corresponding standard errors computed for quantiles 0.1 to

2130.9 in steps of 0.02 .

217 Fig. 4 clearly shows a distinct pattern for the different monitoring sites. However, there are

218 similarities between specific stations in terms of the sign and the distribution over the different 219 quantiles. CCR shows the highest negative slopes over all the analysed sites (from -28 to -19 $220 \mu \mathrm{g} . \mathrm{m}^{-3} / \mathrm{decade}$ ), with a higher decrease observed for the lower quantiles. A negative slope over 221 the all ranges of concentrations is also registered for the north mainland stations - CPB, SEV 222 and PEN - with similar magnitudes (around -5 and $-10 \mu \mathrm{g} \cdot \mathrm{m}^{-3} / \mathrm{decade}$ ) of the quantile 223 distribution pattern. A slight negative slope (>-2.5 $\left.\mu \mathrm{g} \cdot \mathrm{m}^{-3} / \mathrm{decade}\right)$ is also verified for ZAR and 224 BAR, but only for the lower quantiles. 
225 On the opposite, the Atlantic coastal stations - NIB, CUS and PP - have positive slopes over the 226 all concentrations range with the lower increasing at a much faster rate than the middle and 227 upper values. Besides a similar quantile distribution, the magnitude of the slope is significantly 228 different, higher for NIB (> $18 \mu \mathrm{g} \cdot \mathrm{m}^{-3} /$ decade) and lower for CUS and PP ( 5-15 $\mu \mathrm{g} . \mathrm{m}^{-}$

$2293 /$ decade). Positive slopes are also found for the VIZ and TOR stations (4-12 $\mu \mathrm{g} . \mathrm{m}^{-3} / \mathrm{dec}$ ade), 230 both presenting specific and unique quantile distribution.

231 For all cases the derived slopes vary with the quantiles and are distant to the original ordinary 232 least squares slope, indicating that the distribution of the ozone values is not symmetric and the 233 rate of change is not the same for all parts of the data distribution (lower, middle and upper 234 quantiles behave differently).

235 In summary over the last decade a group of stations - CCR, CPB, ZAR, BAR, SEV and PEN 236 registered a decrease mainly on the lower quantiles of $\mathrm{O}_{3}$ data distribution which reflect the 237 minimum (nocturnal) values over these areas. On the opposite, the rest of the monitoring sites 238 NIB, PP, CUS, TOR and VIZ - exhibit a high positive slope on these lower quantiles, indicating 239 an increase over the background values of ozone.

240 Furthermore, the results of the clustering procedure, together with the spatial representation of 241 the quantile slopes, are shown in Fig. 5.

245 The dendrogram for the lower quantile (P5) clearly discriminates three groups: stations with 246 larger negative slopes, $\cong-28 \mu \mathrm{g} \cdot \mathrm{m}^{-3} /$ decade (CCR), slight negative slopes (BAR, SEV, CPB, 247 PEN and ZAR) and the remaining stations with positive slopes (NIB, PP, CUS, TOR, VIZ). 248 These results corroborate the previous analysis, namely in what concerns the different trend on the background ozone values registered over Iberian Peninsula. The second cluster, with positive slopes, further distinguishes the station with the highest slope, $>18 \mu \mathrm{g} \cdot \mathrm{m}^{-3} / \mathrm{decade}$ (NIB) from the other stations. The third cluster, with negative slopes, further subdivides into sites with moderate slopes and stations with very small or non-significant trends (BAR). A similar pattern is found in the dendrogram for the median quantile (P50), with the same groups identified.

255 The dendrogram for the upper quantile (P95) continues to distinguish the CCR station with the highest negative slopes, $>-20 \mu \mathrm{g} \cdot \mathrm{m}^{-3} /$ decade. Within the remaining stations, and differing from the previous dendograms, the major subdivision clusters include (1) the rural stations with positive trend (TOR, NIB and VIZ) and (2) all the other stations with negative slopes and the two suburban stations. This last cluster is then subdivided into two clusters of slight/moderate

260 slopes (ZAR, CUS, BAR and PP) and a cluster of stations with high absolute negative slopes, typically $<-4 \mu \mathrm{g} . \mathrm{m}^{-3} /$ decade (SEV, PEN and CPB). 


\section{5. DISCUSSSION AND CONCLUSIONS}

264 Quantile regression and clustering analysis are applied to study changes in hourly $\mathrm{O}_{3}$ data over 265 the Iberian Peninsula on the last decade (2000-2009). Ozone data was collected from 11 266 background monitoring stations, spatially distributed along the IP, characterized by different 267 background values that goes from $30 \mu \mathrm{g} \cdot \mathrm{m}^{-3}$ (suburban stations on the coast of Portugal) to 80 $268 \mu \mathrm{g} \cdot \mathrm{m}^{-3}$ (stations located in centre and east of IP).

269 Quantile regression allows computing trends at different quantiles of the $\mathrm{O}_{3}$ data distribution 270 within a well-defined statistical framework. In addition, the classical clustering procedure 271 allows summarising the resulting distributions of sample quantile slopes. As in ordinary 272 regression, the slopes for a fixed quantile are not the same over IP, reflecting the spatial 273 dependence of $\mathrm{O}_{3}$ trends. The results for all monitoring sites show different slopes for the 5\%, $27450 \%$ and $95 \%$ percentiles, indicating a different rate of temporal change for all parts of the data distribution, as implicitly assumed in ordinary regression. Lower (P5), middle (P50) and upper (P95) quantiles behave differently, with the lower quantiles of $\mathrm{O}_{3}$ data distribution increasing/decreasing at a much faster rate than the middle and higher quantiles.

278 For example, the CCR station located in the eastern extreme of IP, under influence of different 279 climatic patterns and topographic features, exhibit a very distinct behaviour, with a strong 280 negative trend $\left(<-20 \mu \mathrm{g} \cdot \mathrm{m}^{-3} /\right.$ decade) over all the data distribution, with a higher decrease 281 observed for the lower quantiles (background values) $\left(\sim-28 \mu \mathrm{g} \cdot \mathrm{m}^{-3} / \mathrm{decade}\right)$. CPB, SEV and 282 PEN - located in the interior north part of IP - show a slight negative slope mainly for the lower quantiles $\left(-10 \mu \mathrm{g} \cdot \mathrm{m}^{-3} / \mathrm{decade}\right)$. On the other hand, a positive slope $\left(8-18 \mathrm{ug} \cdot \mathrm{m}^{-3} / \mathrm{decade}\right)$ can be identified for the stations - NIB, CUS and PP - sited over the Atlantic Ocean coast and also TOR and VIZ (4-12 $\mu \mathrm{g} \cdot \mathrm{m}^{-3} / \mathrm{decade}$ ), sited over the Mediterranean influence, and mainly on the lower quantiles of $\mathrm{O}_{3}$ data distribution (background values). This larger trend in the lower quantiles than in the central and upper part of the data distribution was not found in studies conducted over North America where higher hourly average $\mathrm{O}_{3}$ concentrations decrease faster than the mid- and lower-values (Lefohn et al., 2008).

290 The analysis of the clusters for different quantiles reflects the differences existent mainly 291 between the lower/middle and the upper quantile. The dendrograms for the lower and median clearly discriminate three groups: stations with larger negative slopes (CCR), slight negative slopes (BAR, SEV, CPB, PEN and ZAR) and the remaining stations with positive slopes (NIB, PP, CUS, TOR, VIZ). The dendrogram for the upper quantile displays a distinct picture: continues to distinguish the CCR station with the highest negative slopes, but the remaining stations are classified in several sub-clusters with minor significance. In fact, the minor gradient of spatial variability occurs at the $95 \%$ quantile, with slopes ranging from $-8 \mu \mathrm{g} \cdot \mathrm{m}^{-3} / \mathrm{decade}$ to 8 $\mu \mathrm{g} \cdot \mathrm{m}^{-3} /$ decade. 
In summary, this complementary analysis pointed out that the largest trends are found for the

300 lower $\mathrm{O}_{3}$ values, with the largest negative trend at the easternmost station of the IP (CCR), and

301 also in northern and mainland stations (BAR, SEV, CPB and PEN), and an opposite behaviour

302 is detected at the Atlantic coastal stations (NIB, CUS and PP) with positive $\mathrm{O}_{3}$ trends.

303

\section{ACKNOWLEDGEMENTS}

305 The authors gratefully acknowledge the Portuguese 'Ministério da Ciência, da Tecnologia e do 306 Ensino Superior' for the BIOGAIR (PTDC/AAC-AMB/103866/2008) project, for the Ph.D 307 grant of Isabel Ribeiro (SFRH/ BD/60370/2009) and the post-doc grant of Alexandra Monteiro 308 (SFRH/BPD/63796/2009). The acknowledge is extended to the CRUP and the Ministerio de 309 Ciencia e Innovación of Spain by the support of the Integrated Action E 122-10/PT2009-0029. 310 The Spanish Ministry of Science and Innovation is also thanked for the Formación de Personal 311 Investigador (FPI) doctoral fellowship held by María Teresa Pay (CGL2006-08903).

312

\section{REFERENCES}

314 Adame J.A., Lozano A., Bolívar J.P., De la Morena B.A., Conteras J., Godoy F., 2008.

315 Behavior, distribution and variability of surface ozone at an arid region in the south of Iberian 316 Peninsula (Sevilla, Spain). Chemosphere 70, 841-849.

317 Alonso A.M., Berrendero JR, Hernández A, Justel A., 2006. Time series clustering based on 318 forecast densities. Comput. Statist. Data Anal., 51 (2), 762-776.

319 Baldasano J.M., Cremades L., Soriano C., 1994. Circulation of air pollutants over the Barcelona 320 geographical area in summer. Proceedings of Sixth European Symposium Physic-Chemical 321 Behaviour of Atmospheric Pollutants. Varese, Italy, 18-22 October. Report EUR 15609/1 EN: $322 \quad 474-479$.

323 Barbosa S.M., Scotto M.G., Alonso A.M., 2011. Summarising changes in air temperature over 324 central Europe by quantile regression and clustering. Nat. Hazards Earth Syst. Sci. (in press).

325 Baur D., Saisana M., Schulze N., 2004. Modelling the effects of meteorological variables on 326 ozone concentration - a quantile regression approach. Atmos. Environ., 38, 4689-4699.

327 Brönnimann S., Buchmann B., Wanner H., 2002. Trends in near-surface ozone concentrations 328 in Switzerland: the 1990s. Atmos. Environ., 36, 2841-2852.

329 Cade B., Noon B., 2003. A Gentle introduction to quantile regression for ecologists. Frontiers in 330 Ecology and the Environment, 1, 412-420. 
331 Carvalho A.C., Carvalho A., Martins H., Marques C., Rocha A., Borrego C., Viegas D.X.,

332 Miranda A.I. (2011). Fire weather risk assessment under climate change using a dynamical

333 downscaling approach. Environmental Modelling and Software 26 (9), 1123-1133.

334 CEC, 1991, Commission of the European Communities CEC, 1991. Council directive amending 335 directive 70/220/EEC on the approximation of the laws of member states relating to the 336 measures to be taken against air pollution by emissions from motor vehicles. 91/441/EEC. 337 Journal of the European Communities, L242/1-L242/106.

338 Derwent R., Jenkin M., Saunders S., Pilling M., Simmonds, P., Passant, N., Dollard, G., 339 Dumitrean P., Kent A., 2003. Photochemical ozone formation in north west Europe and its 340 control. Atmos. Environ., 37, 1983-1991.

341 Derwent R.G., Simmonds P.G., O’Doherty S., Stevenson D.S., Collins W.J., Sanderson M.G., 342 Johnson C.E., Dentener F., Cofala J., Mechler R., Amann M., 2006. External influences on 343 Europe's air quality: baseline methane, carbon monoxide and ozone from 1990 and 2030 at 344 Mace Head, Ireland. Atmos. Environ., 40, 844-855.

345 Derwent R.G., Simmonds P.G., Manning A.J., Spain T.G., 2007. Trends over a 20-year period 346 from 1987 to 2007 in surface ozone at the atmospheric research station, Mace Head, Ireland. 347 Atmos. Environ., 41, 9091-9098.

348 EEA, 2010a. The European Environment. State and outlook 2010. Air pollution. European 349 Environmental Agency. Luxembourg, Pulication Office of the European Union. ISBN 978-92350 9213-152-4. doi: 10.2800/57792.

351 EEA, 2010b. Air pollution by ozone across Europe during summer 2009. Overview of 352 exceedances of EC ozone threshold values for April-September 2009. Technical Report 2/2010. 353 Euroepan Environmental Agency.

354 Elsner J.B., Kossin J.P., Jagger T.H., 2008.The increasing intensity of the strongest tropical 355 cyclones. Nature 455, 92-95.

356 Gangoiti G., Millán M.M., Salvador R., Mantilla E., 2001. Long-range transport and re357 circulation of pollutants in the western Mediterranean during the project Regional Cycles of Air 358 Pollutions in the West-Central Mediterranean Area. Atmos. Environ., 35, 6267-6276.

359 Gimeno L., Hernández E., Rúa A., García R., Martín I., 1999. Surface ozone in Spain. 360 Chemosphere, 38, 3061-3074. 
361 Honrath R.E., Owen R.C., Val Martin M., Reid J.S., Lapina K., Fiahlo P., Dziobak M.P.,

362 Kleissel J., Westphal D.L., 2004. Regional and hemispheric impacts of anthropogenic and

363 biomass burning emissions on summertime $\mathrm{CO}$ and $\mathrm{O}_{3}$ in the North Atlantic lower free

364 troposphere. J. Geophys. Res., 109, D24310.

365 Jaffe D., Price H., Parrish D., Goldstein A., Harris J., 2003. Increasing background ozone during

366 spring on the west coast of North America. Geophys. Res. Lett., 30(12), 1613, 367 doi:10.1029/2003GL017024.

368 Jenkin M., 2008. Trends in ozone concentration distributions in the UK since 1990: Local,

369 regional and global influences. Atmos. Environ.., 42, 5434-5445.

370 Jorba, O., Pérez, C., Rocadenbosch, F., Baldasano, J. M., 2004. Cluster Analysis of 4-Day Back

371 Trajectories Arriving in the Barcelona Area, Spain, from 1997 to 2002. Journal of Applied

372 Meteorology, 43(6), 887-901.

373 Jonson J. E., Simpson D., Fagerli H., Solberg S., 2005. Can we explain the trends in European 374 ozone levels? Atmos. Chem. Phys., 6, 51- 66.

375 Koenker R., 2005. Quantile regression. Cambridge University Press, New York.

376 Koenker R., Basset G., 1978. Regression quantiles. Econometrica, 46, 33-50.

377 Koenker R., D’Orey V., 1987. Computing regression quantiles. Applied Statistics, 36, 383-393.

378 Koenker R., Schorfheide F., 1994. Quantile spline models for global temperature change. 379 Climatic Change, 28, 395-404.

380 Koenker R., Hallock, K., 2001. Quantile Regression. Journal of Economic Perspectives, 15, $381 \quad 143-156$.

382 Lefohn A., Shadwick D., Oltmans S., 2008. Characterizing long-term changes in surface ozone 383 levels in the United States (1980-2005). Atmos. Environ., 42, 8252-8262.

384 Martín-Vide J., Olcina J., 2001. Climas y tiempos de España. Ed. Alianza, Madrid, 258 pp.

385 Marenco A., Gouget H., Nedelec P., Pages J.-P., 1994. Evidence of a long term increase in 386 tropospheric ozone from Pic du Midi data series: Consequences: positive radiative forcing. J. 387 Geophys. Res., 99, 16617-16632. 
Millán M.M., Salvador R., Mantilla E., 1997. Photooxidant dyanmics in the Mediterranean

389 basin in summer: Results from European research projects. J. Geophys. Res., 102(D7), 88113908823.

391 Millán M., Sanz M.J., Salvador R., Mantilla, E., 2002. Atmospheric dynamics an ozone cycles related to nitrogen deposition in the western Mediterranean. Environ. Poll., 118, 167-186.

393 Monteiro, A., Vautard, R., Borrego, C., Miranda, A.I., 2005. Long-term simulations of photo 394 oxidant pollution over Portugal using the CHIMERE model. Atmos. Environ., 39, 3089-3101.

395 Monteiro, A., Miranda, A.I., Borrego, C., Vautard, R., 2007. Air quality assessment for 396 Portugal. Science of the Total Environment 373, 22-31.

397 Oltmans S.J., Lefohn A.S., Harris J.M., Galbally I., Scheel H.E., Bodeker G., Brunke E., Claude 398 H., Tarasick D., Johnson B.J., Simmonds P., Shadwick D., Anlauf K., Hayden K., Schmidlin F., 399 Fujimoto T., Akagi K., Meyer C., Nichol S., Davies J., Redondas A., Cuevas E., 2006. Long400 term changes in tropospheric ozone. Atmos. Environ., 40 (17), 3156-3173.

401 Ordonez C., Elguindi N., Stein O., Huijnen V., Flemming J., Inness A., Flentje H., Katragkou 402 E., Moinat P., Peuch V., Segers A., Thouret V., Athier G., van Weele M., Zerefos C., Cammas 403 J., Schultz M., 2010. Global model simulations of air pollution during the 2003 European heat 404 wave. Atmos. Chem. Phys., 10, 789-815.

405 Pay, M.T., Jiménez-Guerrero, P., Jorba, O., Basart, S., Pandolfi, M., Querol, X., Baldasano, 406 J.M., 2011. Spatio-temporal variability of levels and speciation of particulate matter across 407 Spain in the CALIOPE modeling system. Submitted in Atmos. Environ.

408 Pérez C., Sicard M., Jorba O., Comerón A., Baldasano J.M., 2004. Summertime re-circulations 409 of air pollutants over the north-eastern Iberian coast observed from systematic EARLINET lidar 410 measurements in Barcelona. Atmos. Environ., 38, 3983-4000.

411 Ribas A., Peñuelas J., 2004. Temporal patterns of surface ozone levels in different habitats of 412 the north western Mediterranean basin. Atmos. Environ., 38, 985-992.

413 Scotto M.G., Barbosa S.M., Alonso A.M, 2009. Model-based clustering of Baltic sea-level. 414 Appl. Ocean Res., 31, 4-11.

415 Seinfeld J.H., Pandis S.N., 1998. Atmospheric Chemistry and Physics: From air pollution to 416 climate change. John Wiley \& Sons, New York. ISBN: 9780471178163. 
417 Sicard P., Coddeville P., Galloo J., 2009. Near-surface ozone levels and trends at rural stations

418 in France over the 1995-2003 period. Environ. Monit. Assess., 156, 141-157.

419 Soriano C., Baldasano J.M., Buttler W.T., Moore K., 2001. Circulatory patterns of air pollutants 420 within the Barcelona air basin in a summertime situation: liar and numerical approaches. 421 Bound.-Lay. Meteorol., 98, 33-55.

422 Tang G., Li X., Wang Y., Xin J., Ren X., 2006. Surface ozone trend details and interpretations 423 in Beijing, 2001-2006. Atmos. Chem. Phys., 9, 8813-8823.

424 Toll I., Baldasano J.M., 2000. Modeling of photochemical air pollution in the Barcelona area 425 with highly disaggregated anthropogenic and biogenic emissions. Atmos. Environ., 34, 30604263084.

427 Vautard R., Szopa S., Beekmann M., Menut L., Hauglustaine D. A., Rouil L., Roemer M., 2006. 428 Are decadal anthropogenic emission reductions in Europe consistent with surface ozone 429 observations?, Geophys. Res. Lett., 33, L13810, doi:10.1029/2006GL026080.

430 Vingarzan R., 2004. A review of surface ozone background levels and trends. Atmos. Environ., $43138,3431-3442$. 
434 Table captions

435 Table 1. Selected $\mathrm{O}_{3}$ background monitoring stations over the IP.

436

437

\section{$438 \quad$ Figure captions}

439

440 Figure 1. Map of the IP showing the locations of the background monitoring stations considered

441 in the present analysis (Table 1). The bullet size indicates the altitude and the round/square

442 shape the type of the background station (rural/suburban).

443

444 Figure 2. Whisker plots of the hourly $\mathrm{O}_{3}$ concentrations, measured at the selected sites over the

445 IP, depicting the median (P50), the P5-P95 range and the non-outliers range.

446

447 Figure 3 . Time series of hourly $\mathrm{O}_{3}$ concentrations changes per decade $\left(\left[\mu \mathrm{g} \cdot \mathrm{m}^{-3}\right] /\right.$ decade) (solid

448 grey line) and trends for quantiles 0.05 (dashed line), 0.5 (solid line) and 0.95 (dotted line).

449

450 Figure 4. Quantile slopes $\left(\mathrm{O}_{3}\right.$ concentration $\left[\mu \mathrm{g} \cdot \mathrm{m}^{-3}\right] /$ decade $)$ and corresponding standard errors

451 for the selected group of stations. The horizontal dashed line represents the usual ordinary least

452 squares slope.

453

454 Figure 5. Dendrogram for 5\%,50\% and 95\% quantile slopes (right) and the spatial

455 representation of the quantile slopes (left). 


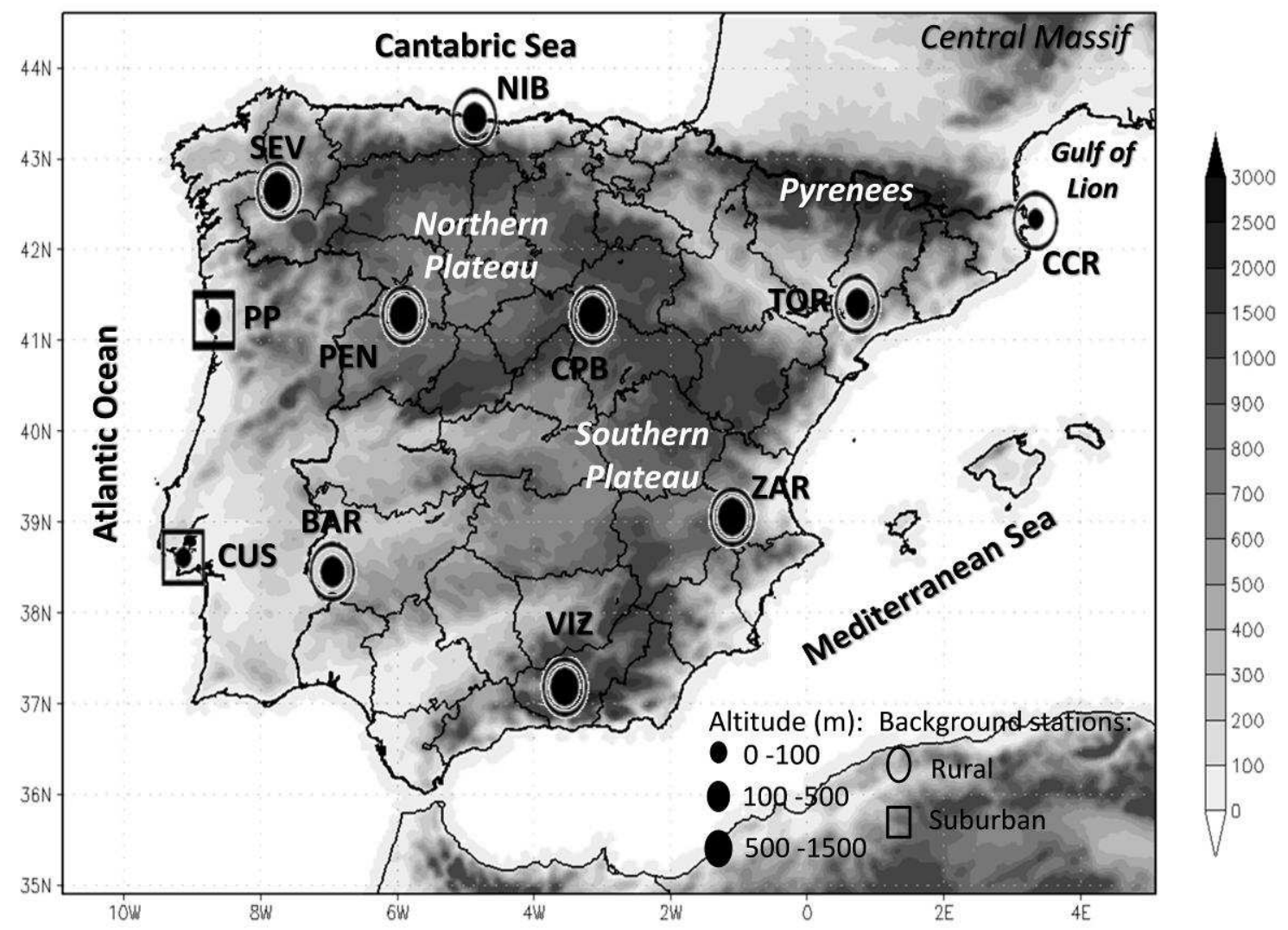



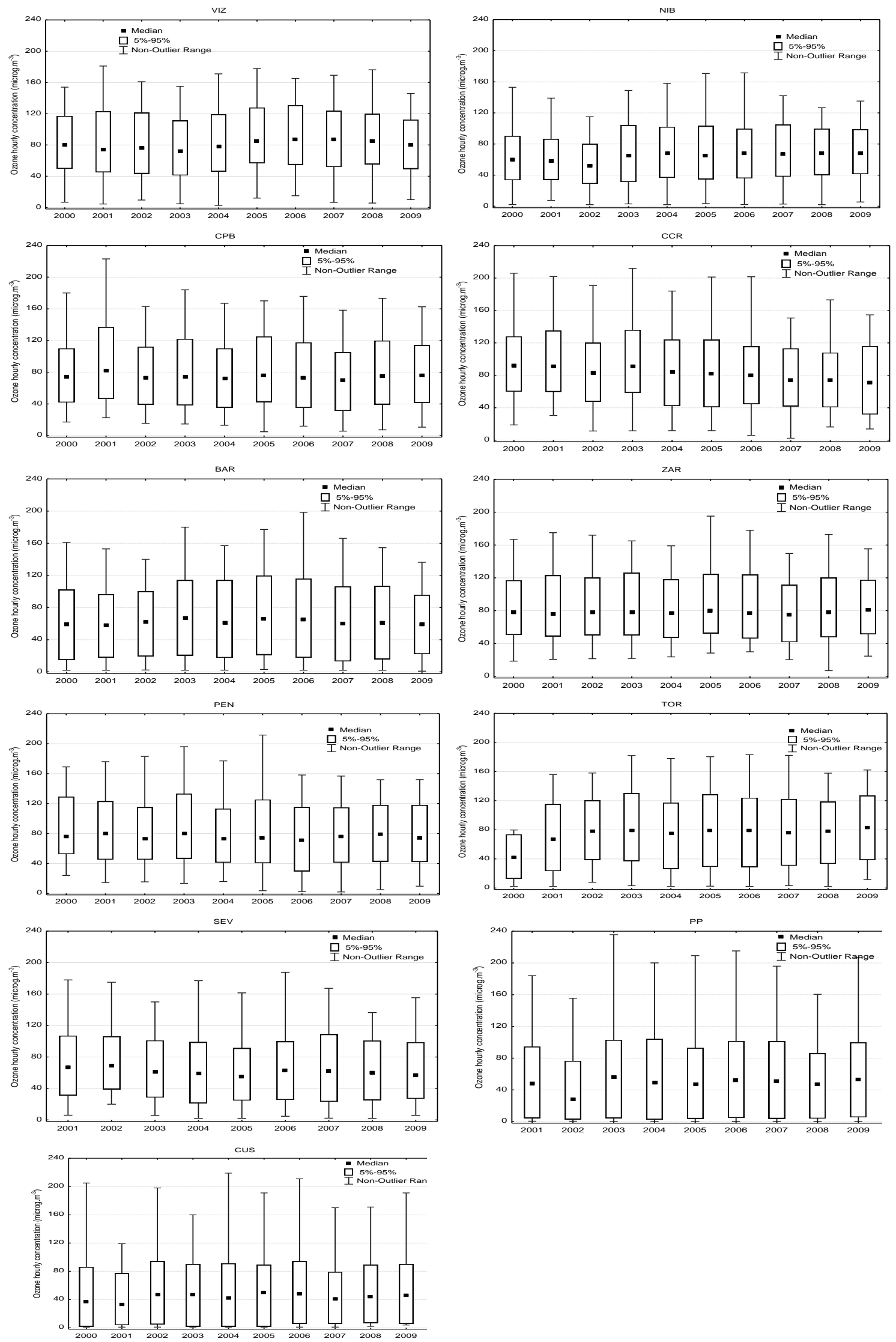

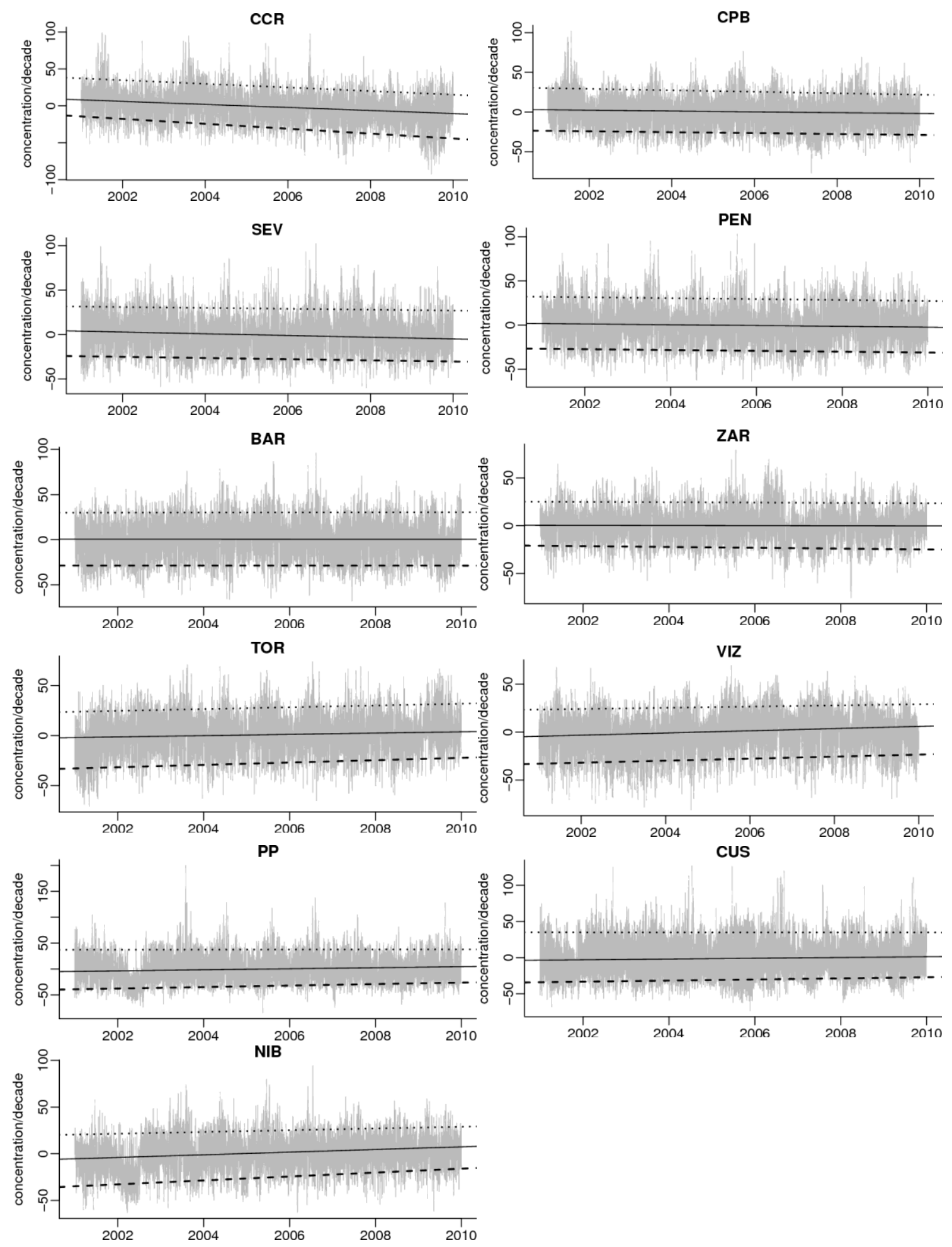


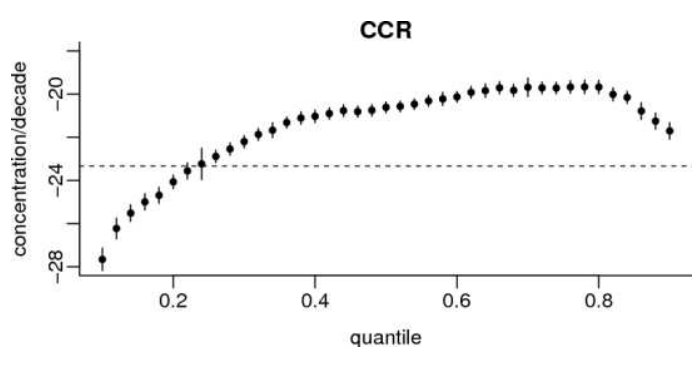

SEV
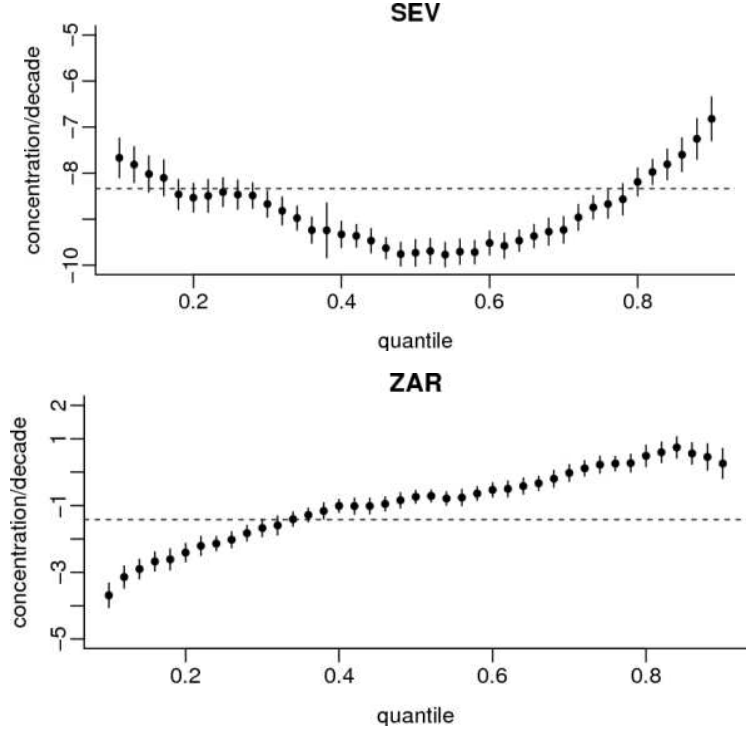

VIZ

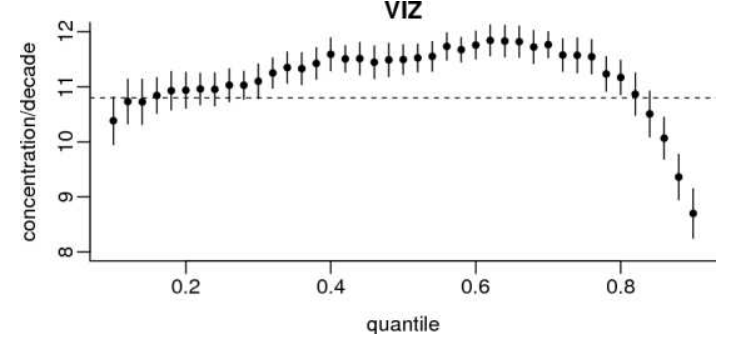

cus

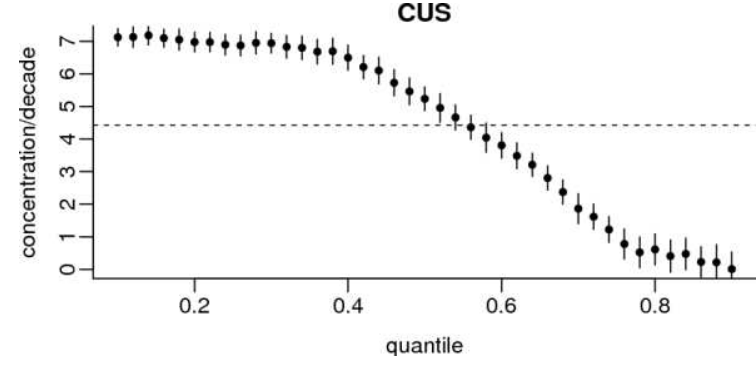

NIB

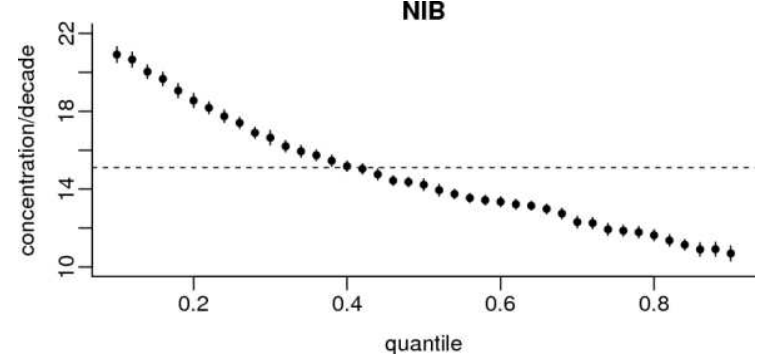

CPB

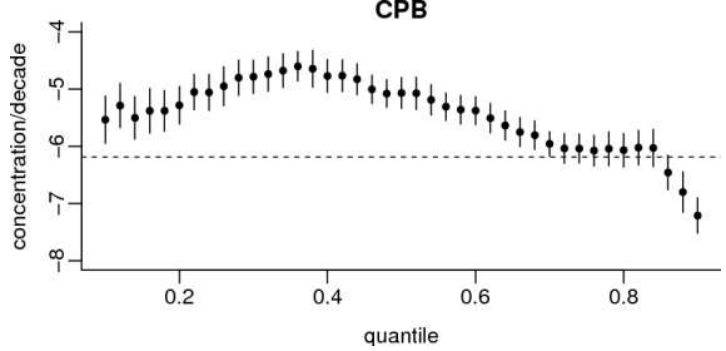

PEN

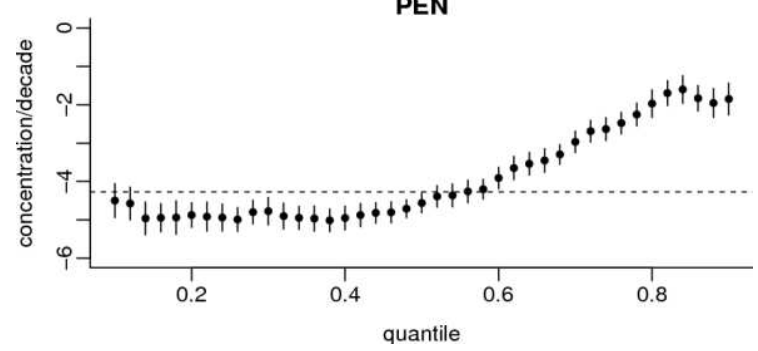

BAR

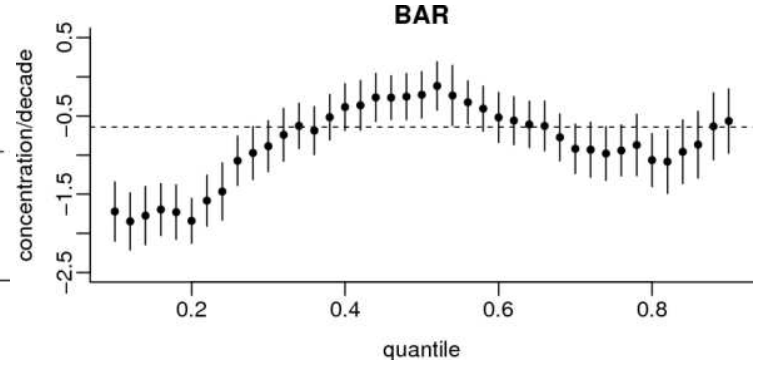

TOR

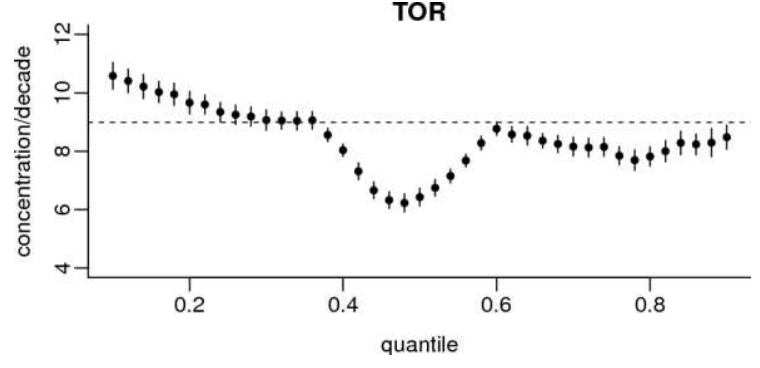

PP

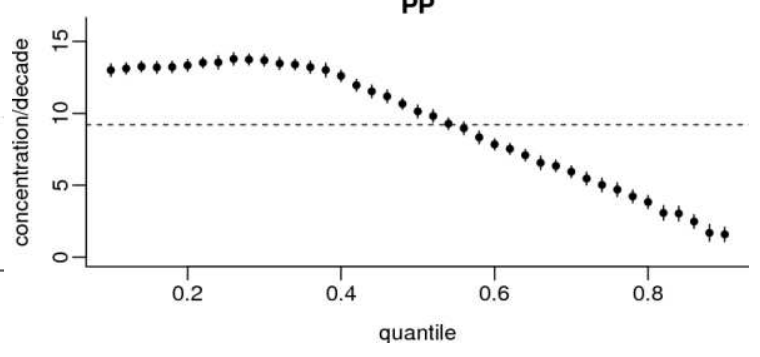



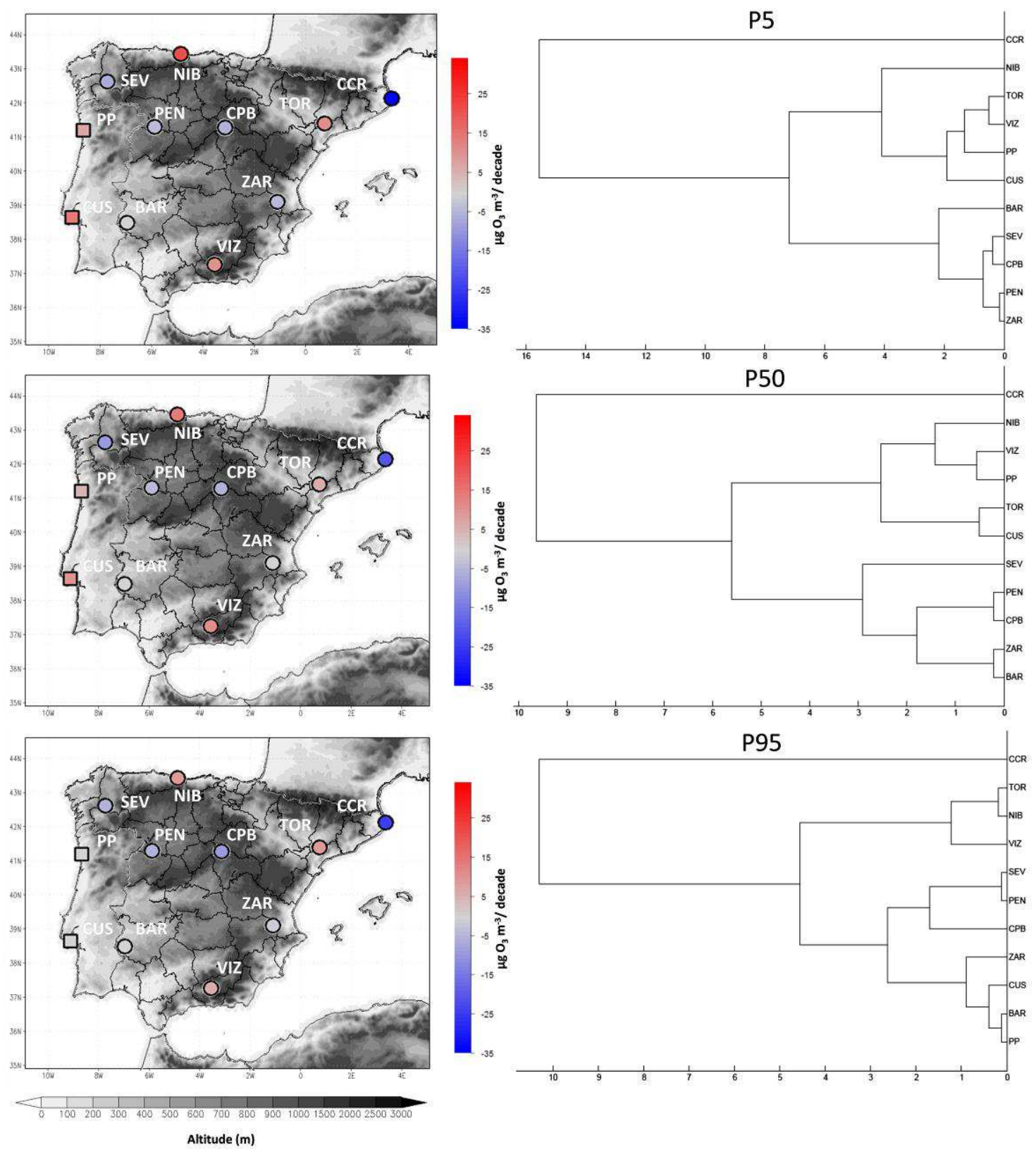


\begin{tabular}{|l|l|l|c|c|l|c|c|}
\hline Code & Station name & Country & Lat & Lon & Type & Data collection (\%) & Altitude (m) \\
\hline CUS & Custóias & Portugal & 41.21 & -8.65 & Suburban & $89.2 \%$ & 100 \\
\hline PP & Paio Pires & Portugal & 38.63 & -9.08 & Suburban & $89.3 \%$ & 46 \\
\hline VIZ & Víznar & Spain & 37.23 & -3.53 & Rural & $97.2 \%$ & 1265 \\
\hline NIB & Niembro & Spain & 43.44 & -4.85 & Rural & $97.6 \%$ & 134 \\
\hline CPB & Campisábalos & Spain & 41.28 & -3.14 & Rural & $95.5 \%$ & 1360 \\
\hline CCR & Cabo de Creus & Spain & 42.32 & 3.32 & Rural & $96.6 \%$ & 23 \\
\hline BAR & Barcarrota & Spain & 38.48 & -6.92 & Rural & $97.0 \%$ & 393 \\
\hline ZAR & Zarra & Spain & 39.08 & -1.10 & Rural & $96.8 \%$ & 885 \\
\hline PEN & Peñausende & Spain & 41.28 & -5.87 & Rural & $91.9 \%$ & 985 \\
\hline TOR & Els Torms & Spain & 41.40 & 0.72 & Rural & $89.7 \%$ & 470 \\
\hline SEV & O Saviñao & Spain & 42.64 & -7.71 & Rural & $85.0 \%$ & 506 \\
\hline
\end{tabular}

